\title{
Isolation and Characterization of a Klebsiella pneumoniae Specific Lytic Bacteriophage from a Hospital Waste-water Treatment Plant
}

\author{
Mahboubeh Soleimani Sasani ${ }^{1}$, Fereshteh Eftekhar ${ }^{1 *}$, Seyed Masoud Hosseini ${ }^{1}$
}

\author{
${ }^{1}$ Department of Microbiology and Microbial Biotechnology, Faculty of Life Sciences and Biotechnology, Shahid \\ Beheshti University, Tehran, Iran
}

Received May 13, 2019; Accepted Jun. 17, 2019

\begin{abstract}
Introduction: Phage therapy has gained interest as a potential alternative for treatment of infections caused by multidrugresistant (MDR) pathogens. This study aimed to isolate a lytic bacteriophage with the potential to lyse clinical isolates of Klebsiella pneumoniae. Methods: Water samples were collected from a hospital waste-water treatment plant in Tehran. The samples were filtered and mixed with an overnight grown culture of K. pneumoniae. (ATCC 10031) followed by incubation at $37^{\circ} \mathrm{C}$ overnight. Phage titration, latent period, and burst size measurements were carried out by the double-layer agar method using the K. pneumoniae ATCC strain. The isolated phage was characterized by transmission electron microscopy (TEM), thermal, $\mathrm{pH}$, and chloroform stability. Susceptibility of Escherichia coli, Acinetobacter baumannii, Pseudomonas aeruginosa, ESBL producing K. pneumoniae and $51 \mathrm{MDR}$ K. pneumoniae isolates was measured by placing $20 \mu \mathrm{l}$ of the phage suspension $\left(10^{8} \mathrm{PFU}\right)$ onto bacterial lawns followed by incubation at $37^{\circ} \mathrm{C}$ overnight. Formation of clear zones indicated susceptibility. Results: The isolated lytic bacteriophage formed small clear plaques with a latent period of $40 \mathrm{~min}$ and a burst time of $52 \mathrm{~min}$, corresponding to 35-40 phage particles per infected cell. TEM results showed that the phage resembled the tailed Siphoviridae family and was designated vB_KpnS-Teh.1. The phage vB_KpnS-Teh.1 was most stable at $37^{\circ} \mathrm{C}, \mathrm{pH} 7$ and was resistant to chloroform. Conclusion: The isolated lytic phage showed specificity towards $K$. pneumoniae. Further research will determine its potential in the treatment of K. pneumoniae infections. J Med Microbiol Infec Dis, 2019, 7 (1-2): 6-11.
\end{abstract}

Keywords: Klebsiella pneumoniae, Bacteriophage, Waste-water, Siphoviridae.

\section{INTRODUCTION}

The Gram-negative opportunistic pathogen, Klebsiella pneumoniae is responsible for severe infections such as septicemia, pneumonia, urinary tract infections (UTI) and soft tissue infections in hospitalized and immunecompromised patients with underlying diseases [1]. Emergence and spread of multidrug-resistant (MDR) $K$. pneumoniae, specifically the extended spectrum $\beta$ lactamase producing strains, is often the cause of antibiotic treatment failure $[2,3]$.

Lytic bacteriophages are obligate parasites which replicate within a particular bacterial host and cause rapid lysis and cell death within a short period. Therefore, the potential use of lytic phages as alternative antimicrobial agents has received much attention for the treatment of multidrug-resistant clinical isolates of bacteria [4-6]. Several studies have reported isolation and characterization of lytic phages with specific activity against Klebsiella spp. and MDR K. pneumoniae isolates [7-10]. Most of these bacteriophages are tailed and belong to the order Caudovirales, which include the families Myoviridae, Siphoviridae, and Podoviridae [11, 12]. The efficacy of some of these phages was also studied in $K$. pneumoniae biofilms as well as animal models of $K$. pneumoniae infections [12-14]. This study aimed to isolate and characterize a lytic bacteriophage from raw waste-waters with activity against $K$. pneumoniae and possible potential for future therapeutic applications.

\section{MATERIAL AND METHODS}

Bacteriophage isolation and purification. Water samples were collected from a hospital waste-water treatment plant in January 2017 in Tehran. To flasks containing $40 \mathrm{ml}$ of wastewater, $5 \mathrm{ml}$ nutrient broth $(10 \mathrm{x}$, Liofilchem, Italy) and $5 \mathrm{ml}$ of overnight grown $K$. pneumoniae (ATCC10031) in nutrient broth were added and incubated at $37^{\circ} \mathrm{C}$ overnight. The culture was centrifuged at $2000 \times \mathrm{g}$ for $15 \mathrm{~min}$, and the recovered supernatant was filtered through $0.22 \mu \mathrm{m}$ pore size filters followed by dilution of the filtrate $(1: 100)$ in phosphate buffered saline (PBS, pH 7). An aliquot of $100 \mu 1$ of the phage preparation and $500 \mu \mathrm{l}$ of $K$. pneumoniae ATCC 10031 (adjusted to $0.5 \mathrm{McF}$ arland standard) were added to $3 \mathrm{ml}$ soft nutrient agar $\left(0.75 \%\right.$ agar at $\left.45^{\circ} \mathrm{C}\right)$. The mixture was then layered onto a nutrient agar plate and allowed to solidify before incubation at $37^{\circ} \mathrm{C}$ overnight. The

*Correspondence: Fereshteh Eftekhar

Department of Microbiology and Microbial Biotechnology, Faculty of Life Sciences and Biotechnology, Shahid Beheshti University, Tehran, Iran, 1983969411.

Email: f-eftekhar@sbu.ac.ir

Tel: +98 (21) $29905923 \quad$ Fax: +98 (21) 22431664 
appearance of clear plaques indicated the presence of lytic phages. A single clear plaque was isolated for further purification.

Transmission Electron Microscopy (TEM). A hightiter phage preparation $\left(10^{11} \mathrm{PFU} / \mathrm{ml}\right)$ was deposited on a formvar-carbon coated grid $\mathrm{Cu}$ Mesh 300, fixed with $1 \%$ glutaraldehyde, stained with the standard negative staining using $2 \%$ uranyl acetate, and examined by an EM 10C (Zeiss, Germany) transmission electron microscope at 100 $\mathrm{kV}[12]$.

Phage adsorption assay. An overnight culture of $K$. pneumoniae ATCC in Mueller Hinton broth (MHB, Liofilchem, Italy) was adjusted to $10^{8} \mathrm{CFU} / \mathrm{ml}$. Equal volumes of the bacterial culture and phage suspension $\left(10^{7}\right.$ $\mathrm{PFU} / \mathrm{ml}$ ) were mixed and incubated at $37^{\circ} \mathrm{C}$ for 5 and 10 min respectively. The cultures were centrifuged at $10000 \times$ $\mathrm{g}$ for $5 \mathrm{~min}$, filtered through a $0.22 \mu \mathrm{m}$ filter, and the numbers of free phages were determined using the doublelayer agar method. The reduction in phage titer showed the number of phages adsorbed to the bacterial cells [8].

One-step growth curve. One-step growth curve of the isolated phage was performed using the method of Pajunen et al. (2014) with some modifications [15]. Initially, an overnight culture of $K$. pneumoniae ATCC in MHB was adjusted to $10^{8} \mathrm{CFU} / \mathrm{ml}$. For phage adsorption, $0.9 \mathrm{ml}$ of bacterial suspension was mixed with $0.1 \mathrm{ml}$ of the phage $\left(10^{8} \mathrm{PFU}\right)$ (multiplicity of infection, $\left.\mathrm{MOI}=0.1\right)$ and incubated at $37^{\circ} \mathrm{C}$ for $5 \mathrm{~min}$. The mixture was diluted, and samples $(0.1 \mathrm{ml})$ were taken at $5 \mathrm{~min}$ intervals up to $30 \mathrm{~min}$, followed by $15 \mathrm{~min}$ intervals up to $90 \mathrm{~min}$ for determining the number of phages by the double-layer agar method. The latent period, burst time, and burst size were calculated from the one-step growth curve [8]. All assays were carried out at three different times.

Thermal, pH and chloroform stability tests. Thermal stability of the isolated phage was determined by incubation of different phage suspensions $\left(10^{8}-10^{12}\right.$ phage particles $\left./ \mathrm{ml}\right)$ at $50-70^{\circ} \mathrm{C}$ for $2 \mathrm{~h}$ and $24 \mathrm{~h}$, followed by determining the number of phages by the double-layer agar method. For $\mathrm{pH}$ stability tests, $10 \mu \mathrm{l}$ of $10^{11}$ phage suspension was added to $0.99 \mathrm{ml}$ of $\mathrm{MHB}$ at a $\mathrm{pH}$ range of 3-12 and incubated at $37^{\circ} \mathrm{C}$ for $18 \mathrm{~h}$ before phage titration. Chloroform susceptibility was measured by mixing $1 \mathrm{ml}$ of $10^{9}$ phage particles with $1 \mathrm{ml}$ chloroform (Merck, Germany) and the mixture was incubated at $37^{\circ} \mathrm{C}$ for $18 \mathrm{~h}$ before determination of the phage particle numbers [8].

Determination of optimal multiplicity of infection (MOI). K. pneumoniae ATCC strain was grown in MHB at $37^{\circ} \mathrm{C}$ to an optical density (OD) of 0.6 at $600 \mathrm{~nm}$ corresponding to around $10^{8} \mathrm{CFU}$. Bacterial cultures $(1 \mathrm{ml})$ were inoculated with $10^{9}, 10^{8}$, and $10^{7}$ PFUs at the MOIs 10,1 and 0.1 , respectively. Bacterial growth was monitored by recording $\mathrm{OD}_{600}$ at $30 \mathrm{~min}$ intervals up to $360 \mathrm{~min}$ [8].

Determination of host range. Spot test was employed to determine the bacterial host range for the isolated phage using Escherichia coli (ATCC 25922), Acinetobacter baumannii (ATCC BAA-747), Pseudomonas aeruginosa (ATCC 27853) and ESBL producing K. pneumoniae $(207 \mathrm{~L})$ [16]. Bacteria were grown in $\mathrm{MHB}$ for $6-8 \mathrm{~h}$ at $37^{\circ} \mathrm{C}$ to reach the turbidity of $0.5 \mathrm{McF}$ arland. Bacterial lawns were formed on MHA plates, and $20 \mu \mathrm{l}$ of phage suspensions $\left(10^{8} \mathrm{PFU}\right)$ were placed on the bacterial lawns. Plates were incubated at $37^{\circ} \mathrm{C}$ and observed after 6,18 , and $24 \mathrm{~h}$ for phage-mediated lysis [6]. Also, 51 MDR K. pneumoniae clinical isolates were employed in the spot test.

\section{RESULTS}

Morphology. A lytic phage was isolated which formed small clear plaques $(\leq 1 \mathrm{~mm})$ in $K$. pneumoniae ATCC host. TEM results revealed an isometric headed phage with a capsid size of $\sim 40 \pm 2 \mathrm{~nm}$ in diameter and a long noncontractile tail of $\sim 300 \pm 3.0 \mathrm{~nm}$ (Fig. 1), resembling the double-stranded DNA phages of the family Siphoviridae [17]. According to the scheme for the nomenclature of bacterial viruses, the phage was designated vB_KpnSTeh.1 [18].

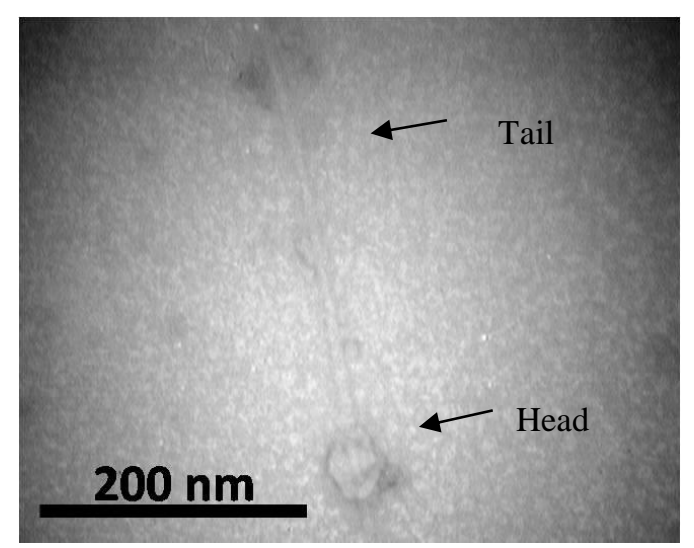

Fig. 1. Transmission electron micrograph of the negatively stained phage vB_KpnS-Teh.1. Black arrows show the head and tail of the phage

Phage adsorption and one-step growth curve. The phage (vB_KpnS-Teh.1) particles were adsorbed to the bacterial host after $5 \mathrm{~min}$ (Fig. 2A). The one-step growth curve revealed a latent period of $40 \mathrm{~min}$ and a burst time of 52 min, corresponding to about $35-40$ phage particles per infected cell (Fig. 2B). 
Thermal, pH and chloroform stability. The vB_KpnS-Teh.1 phage was sensitive to high temperatures. PFU numbers decreased $1 \log$ at $50^{\circ} \mathrm{C}, 3-\operatorname{logs}$ at $60^{\circ} \mathrm{C}$ after $18 \mathrm{~h}$ and 5-6 logs after $2 \mathrm{~h}$ at $70^{\circ} \mathrm{C}$ (Fig. 3A). As shown in Figure $3 \mathrm{~B}$, the phage was stable at $\mathrm{pH} 7$, but $\mathrm{PFU}$ decreased $4 \operatorname{logs}$ at $\mathrm{pH}$ values 5 and 9 . At $\mathrm{pH} 11$ and 3 , the number of the phages reduced 6 and 7 logs, respectively (Fig. 3B). Phage vB-KpnS-Teh.1 was resistant to chloroform at $37^{\circ} \mathrm{C}$ for $18 \mathrm{~h}$.

Optimal multiplicity of infection (MOI). As observed in Figure 4, all tested MOIs were similarly effective against the host strain. Hence, we used the MOI 0.1 in further experiments.

Determination of the phage host range. The spot test results showed that phage vB_KpnS-Teh.1 had no lytic activity against the tested bacteria, E. coli, A. baumannii or $P$. aeruginosa. The lytic activity of the phage was specific to $K$. pneumoniae clinical isolates among which, 8 MDR isolates $(15.7 \%)$ were sensitive to the vB_KpnS-Teh.1 phage.

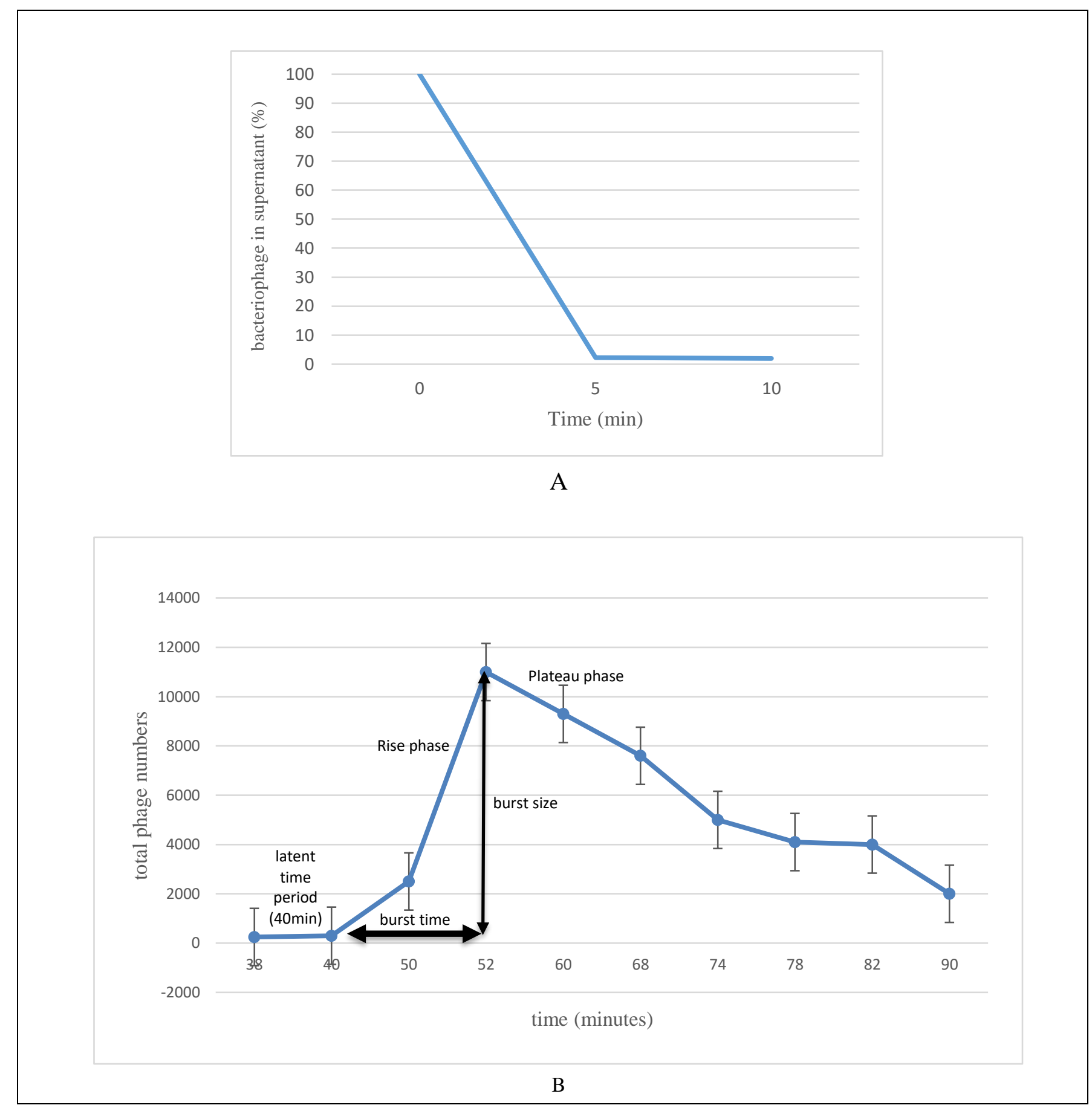

Fig. 2. Adsorption (A) and one-step growth curves of phage vB_KpnS-Teh.1 (B) in K. pneumoniae ATCC strain. Latent period, burst time, and size were calculated from the one-step growth curve. 


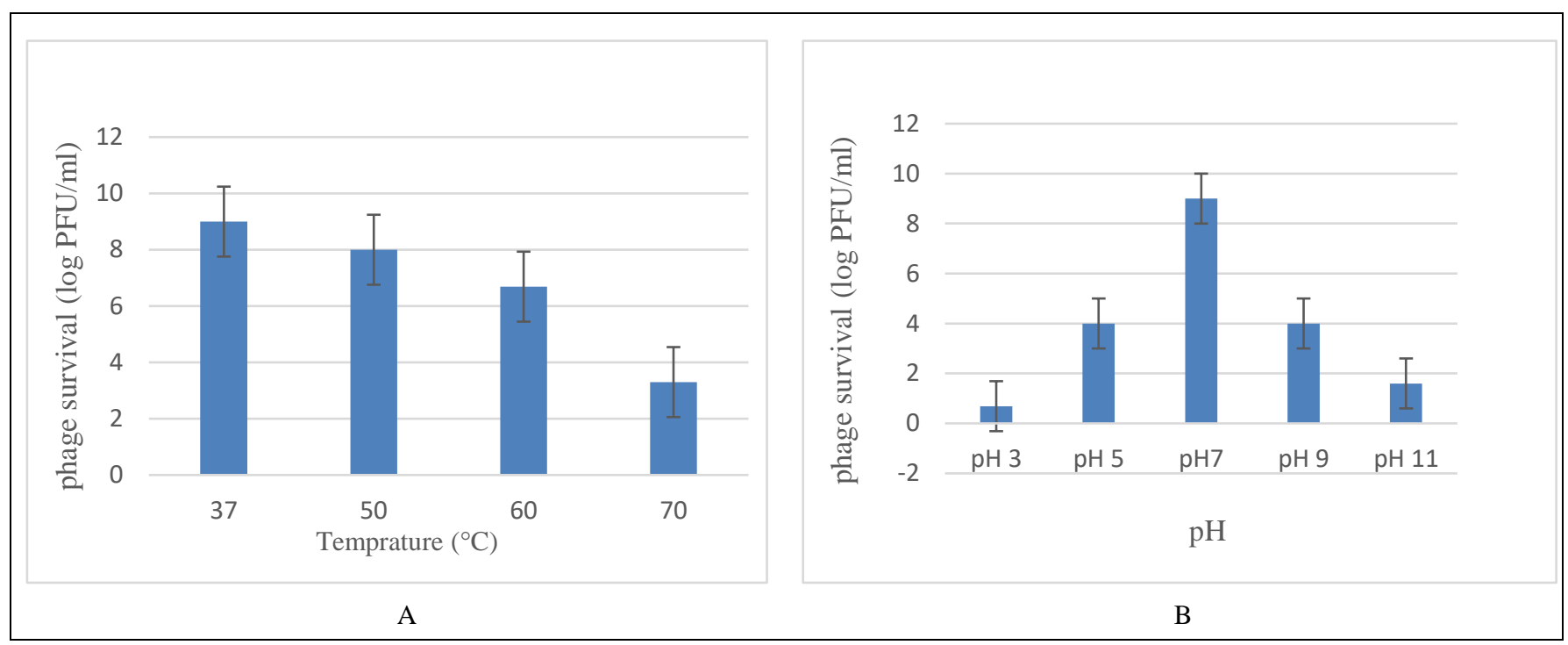

Fig. 3. Thermal (A) and pH stability of phage vB_KpnS-Teh.1 (B)

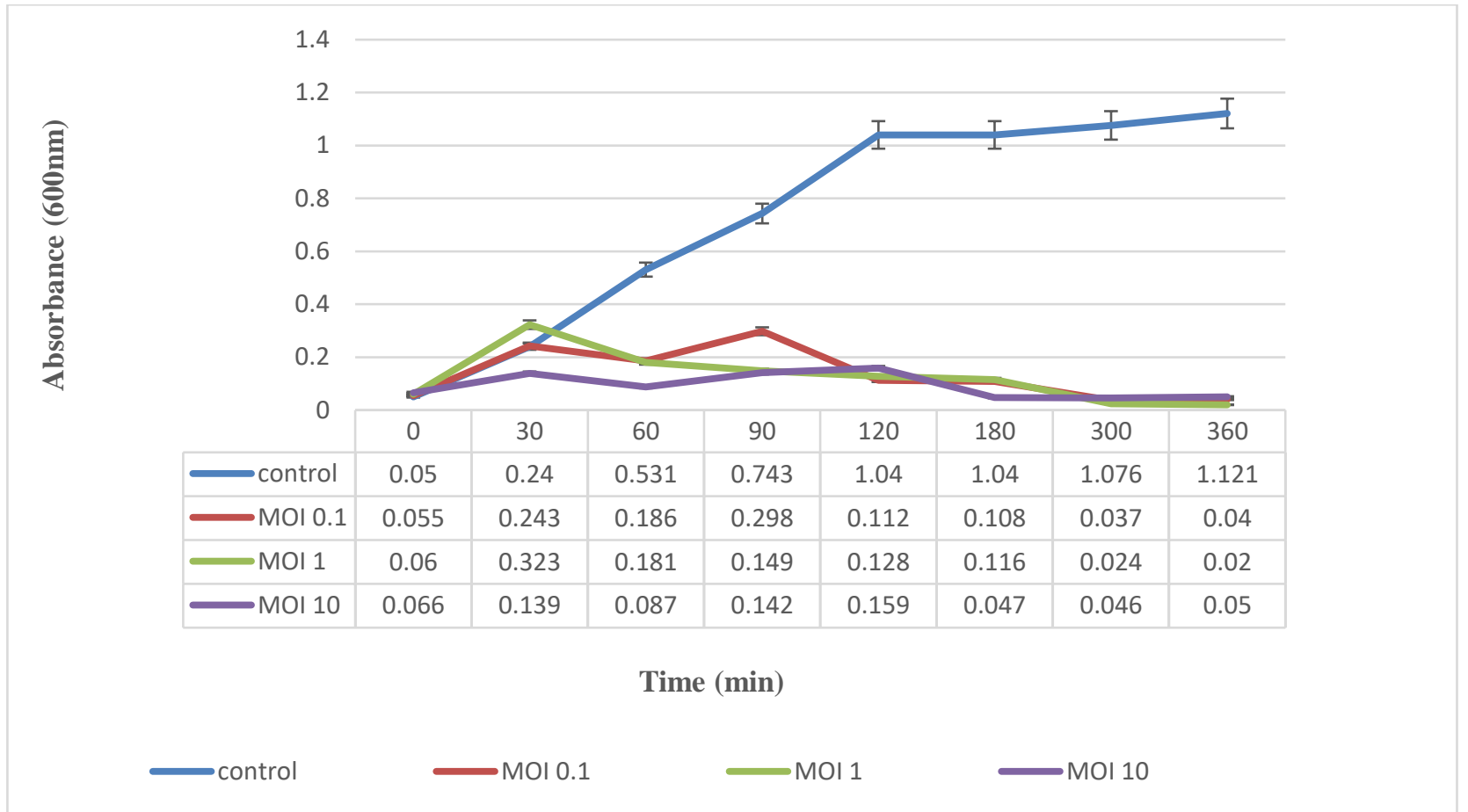

Fig. 4. The efficiency of vB_KpnS-Teh.1 MOI $(0.1,1$ and 10) used to infect the $K$. pneumoniae ATCC strain measured by absorbance of the cultures at $600 \mathrm{~nm}$.

\section{DISCUSSION}

In this study, we isolated a lytic bacteriophage from a hospital waste-water treatment plant which had specific activity against $K$. pneumoniae. TEM results showed that the isolated phage, vB_KpnS-Teh.1, resembled the doublestranded DNA phages belonging to the family Siphoviridae. Other studies have also reported the isolation of $K$. pneumoniae specific lytic phages belonging to the Siphoviridae family $[7,10,12,17]$. The characteristic features of our phage, i.e., the latent period of $40 \mathrm{~min}$, burst time of $52 \mathrm{~min}$ and a burst size of 35-40 were similar to the phages reported by others $[7,10]$. The isolated phage of this study showed resistance to chloroform, was partially stable at high temperatures $\left(50-70^{\circ} \mathrm{C}\right)$ and $\mathrm{pH} 5-9$, and retained residual activity at $\mathrm{pHs} 3$ and 11 . Interestingly, about twothirds of tailed phages, including the members of Siphoviridae family are chloroform-resistant [10]. Similar to our results, Jamal et al. (2015) reported a Siphoviridae phage, designated $\mathrm{Z}$, with stability at $37-70^{\circ} \mathrm{C}$ and activity at a wide $\mathrm{pH}$ range of 5-11 [12]. In another study, an isolated $K$. pneumoniae lytic phage showed thermostability at $30-40^{\circ} \mathrm{C}$ but lost total activity at $60^{\circ} \mathrm{C}$. This phage was 
stable at $\mathrm{pH}$ values of 6 to 10, but retained partial activity at pH 5 and 11 [19]. Karumidze et al. (2013) also isolated a $K$. pneumoniae specific phage, which was stable at $37^{\circ} \mathrm{C}$ and $50^{\circ} \mathrm{C}$ and $\mathrm{pH}$ values of 3 to 9 after $24 \mathrm{~h}$ of incubation [7].

The vB_KpnS-Teh.1 phage showed a narrow range of lytic activity against K. pneumoniae and lysed only $15.7 \%$ (8 out of 51) ESBL-positive isolates. In other studies, members of the Siphoviridae were reported to exhibit similar activity against $K$. pneumoniae, lysing $7-15 \%$ of MDR isolates $[10,12,19,20]$. These phages multiply more efficiently and elicit faster elimination of their bacterial hosts [10]. Characterization of phages provides us a better understanding of their biology, including host specificity, adaptation to bacterial defense systems, and propagation dynamics in natural systems. The knowledge can assist us in exploiting them as therapeutic agents against MDR bacterial pathogens. Also, even though an isolated phage may act specifically against a particular pathogen, the use of phage cocktails consisting of several known lytic phages can increase their efficacy as therapeutic agents against MDR isolates. The therapeutic use of phage cocktails could also prevent the development of resistance among bacterial pathogens [21].

The isolated $K$. pneumoniae phage vB_KpnS-Teh.1 resembled the double-stranded DNA phages belonging to the family Siphoviridae. Our recovered phage had a narrow host range and could lyse only $15.7 \%$ of the ESBL producing MDR clinical isolates of $K$. pneumoniae. The narrow host range could be advantageous in phage therapy since it lowers the possibility of affecting other members of the normal flora.

\section{ACKNOWLEDGMENT}

This research was approved and funded by Shahid Beheshti University Research Council (Grant No. 600/1724).

\section{CONFLICT OF INTEREST}

The authors declare that there are no conflicts of interest associated with this manuscript.

\section{REFERENCES}

1. Podschun R, Ullmann U. Klebsiella spp. as nosocomial pathogens: epidemiology, taxonomy, typing methods and pathogenicity factors. Clin Microbiol Rev. 1998; 11: 589-603.

2. Paterson DL, Bonomo RA. Extended-spectrum $\beta$-lactamases: a clinical update. Clin Microbiol Rev. 2005; 18: 657-86.

3. Bradford PA. Extended-spectrum $\beta$-lactamases in the $21 \mathrm{st}$ century: characterization, epidemiology, and detection of this important resistance threat. Clin Microbiol Rev. 2001; 14: 93351.

4. Harper DR, Enright MC. Bacteriophages for the treatment of Pseudomonas aeruginosa infections. J Appl Microbiol. 2011; 111: 1-7.

5. Soothill J, Hawkins C, Anggard E, Harper D. Therapeutic use of bacteriophages. Lancet Infect Dis. 2004; 4: 544-5.
6. Manjunath NS, Agsar D, Jagannath KV, Rangaswamy BE, Rao SC, Anand S, et al. Characterization and in vitro efficacy studies of wide host range lytic bacteriophage $\Phi$ dmec-1 Infecting Escherichia coli isolated from pyogenic skin infections. DAMA Int. 2013; 2 (2): 47-54.

7. Karumidze N, Kusradze I, Rigvava S, Goderdzishvili M, Rajakumar K, Alavidze Z. Isolation and characterisation of lytic bacteriophages of Klebsiella pneumoniae and Klebsiella oxytoca. Current Microbiol. 2013; 66 (3): 251-8.

8. Drulis-Kawa Z, Mackiewicz P, Kęsik-Szeloch A, Maciaszczyk-Dziubinska E, Weber-Dąbrowska B, Dorotkiewicz-Jach A, et al. Isolation and characterisation of KP34-a novel $\varphi$ KMV-like bacteriophage for Klebsiella pneumoniae. Appl Microbiol Biotechnol. 2011; 90 (4): 1333-45.

9. D'Andrea MM, Marmo P, Henrici De Angelis L, Palmieri M, Ciacci N, Di Lallo, et al. $\varphi$ BO1E, a newly discovered lytic bacteriophage targeting carbapenemase-producing Klebsiella pneumoniae of the pandemic Clonal Group 258 clade II lineage. Sci Reports. 2017; 7: 2614.

10. Kęsik-Szeloch A, Drulis-Kawa Z, Weber-Dąbrowska B, Kassner J, Majkowska-Skrobek G, Augustyniak D, et al. Characterising the biology of novel lytic bacteriophages infecting multidrug resistant Klebsiella pneumoniae. Virol. 2013; $10(1): 1-12$.

11. Simoliūnas E, Kaliniene L, Truncaite L, Zajanckauskaite A, Staniulis J, Kaupinis A, Ger M, Valius M, Meskys R. Klebsiella phage vB_KleM-RaK2 - a giant singleton virus of the family Myoviridae. PLoS One. 2013; 8 (12): e60717.

12. Jamal M, Hussain T, Das CR, Andleeb S. Characterization of Siphoviridae phage $\mathrm{Z}$ and studying its efficacy against multidrug-resistant Klebsiella pneumoniae planktonic cells and biofilm. J Med Microbiol. 2015; 64 (4): 454-62.

13. Hung $\mathrm{CH}$, Kuo $\mathrm{CF}$, Wang $\mathrm{CH}$, Wu $\mathrm{CM}$, Tsao $\mathrm{N}$. Experimental phage therapy in treating Klebsiella pneumoniaemediated liver abscesses and bacteremia in mice. Antimicrob Agent Chemother. 2011; 55 (4): 1358-65.

14. Cao F, Wang X, Wang L, Li Z, Che J, Wang L, et al. Evaluation of the efficacy of a bacteriophage in the treatment of pneumonia induced by multidrug resistance Klebsiella pneumoniae in mice. Biomed Res Int. 2015; Article ID 752930.

15. Pajunen M, Kiljunen S, Skurni M. Bacteriophage fYeO3-12, specific for Yersinia enterocolitica serotype O: 3 is related to coliphages T3 and T7. J Bacteriol. 2000; 182 (18): 5114-20.

16. Raei F, Eftekhar F, Feizabadi MM. Prevalence of quinolone resistance among extended-spectrum $\beta$-lactamase producing uropathogenic Klebsiella pneumoniae. Jundishapur J Microbiol. 2014; 7 (6): e10887.

17. Fokine A, Rossmann MG. Molecular architecture of tailed double-stranded DNA phages. Bateriophage. 2014; 4: e28281.

18. Kropinski AM, Prangishvili D, Lavigne R. The creation of a rational scheme for the nomenclature of viruses of Bacteria and Archaea. Environ Microbiol. 2009; 11: 2775-7.

19. Komijani M, Bouzari M, Rahimi F. Detection and characterization of a novel lytic bacteriophage (vB-KpneMIsf48) against Klebsiella pneumoniae isolates from infected 
wounds carrying antibiotic-resistance genes (TEM, SHV, and CTX-M). Iran Red Crescent Med J. 2017; 19 (2): e34475.

20. Carl G, Jäckel C, Grützke J, Hertwig S, Grobbel M, Malorny B, et al. Complete genome sequence of the temperate Klebsiella pneumoniae phage KPP5665-2. Genome Announc. 2017; 5 (43): e01118-17.
21. Chadha P, Katare OP, Chhibber S. Liposome loaded phage cocktail: Enhanced therapeutic potential in resolving Klebsiella pneumoniae mediated burn wound infections. Burns. 2017; 43 (7): 1532-43. 